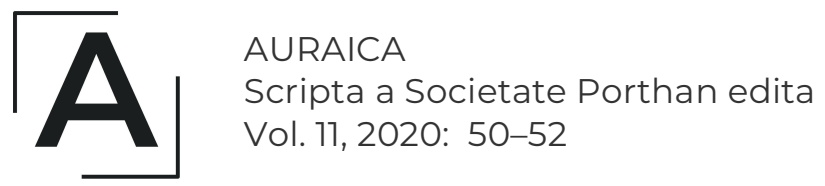

\title{
Franska vetenskapsmän i 1700-talets Lappland
}

\author{
Charlotta Wolff
}

Pierre Louis Moreau de Maupertuis, Maan muoto ynnä muita kirjoituksia Lapista. Toimittanut ja selityksin varustanut Osmo Pekonen, Maupertuis'n tekstit suomentaneet Marja Itkonen-Kaila ja Osmo Pekonen, Väyläkirjat, Rovaniemi, 2019, 266 s.

Docenten i lärdomshistoria Osmo Pekonen är bekant för många som den finska matematikern som populariserat vetenskapshistoria och särskilt fransk-nordiska akademiska förbindelser i ett stort antal publikationer sedan 1990-talet, börjande med Ranskan tiede, som utkom 1995. Han är också känd som essäist, dagboksförfattare och översättare av såväl prosa som modern och äldre lyrik. En av hans viktigaste uppgifter har varit att göra den franska naturvetenskapliga forskningen och litteraturen tillgänglig också för en finsk publik. Det är i detta sammanhang man bör se också den nya boken Maan muoto.

Pekonen disputerade 1988 i Jyväskylä på en avhandling i differentialgeometri, en gren av matematiken som ligger till grunden för lantmäteri och geodesi, det vill säga kunskapen om jordens figur och storlek. Detta ligger bakom hans djupa intresse och förståelse för Pierre Louis Moreau de Maupertuis (1698-1759), som i Finland och Sverige är känd framför allt för den expedition han år 1736-1737 ledde till Lappland för att mäta jordens omkrets. Pekonen har gett ut en låg rad studier om Maupertuis och Lappland, i form av såväl populärvetenskapliga artiklar som monografier och översättningar. Pekonen disputerade för andra gången år 2010 vid Lapplands universitet på avhandlingen La rencontre des religions autour du voyage de l'abbé Réginald Outhier en Suède en 1736-1737 (Lapland University Press, Rovaniemi), vilken behandlade uttryckligen denna expedition utgående från abbé Outhiers anteckningar. Till samma tematik hör Pekonens översättning av Maupertuis Venus physique (Fyysinen Venus, Art House, Helsingfors, 2017), hans källkritiska utgåva av Maupertuis skrifter om Lappland (Maupertuis en Laponie, tillsammans med Anouchka Vasak, Hermann, Paris, 2014), och hans översättning av Mary Terralls biografi över Maupertuis (Maupertuis, maapallon muodon mittaaja, Väyläkirjat, Rovaniemi, 2015). Upplysningstidens vetenskapliga kretsar behandlas utförligt även i Pekonens och Johan Sténs Valon aika från 2019 (Art House, Helsingfors).

Med Maan muoto ynnä muita kirjoituksia Lapista sluter Pekonen cirkeln kring Maupertuis. Det är dels en källutgåva, dels en samling essäer som anknyter till den franska vetenskapsakademins expedition till Lappland 1736-1737. Boken omfattar ett 
förord och en introduktion av Osmo Pekonen, översättningarna av två brev och två vetenskapliga texter av Maupertuis, sju essäer av Pekonen (en skriven tillsammans med Johan Stén), en mycket omfattande och tacknämlig litteraturförteckning samt ett fullständigt personregister. Översättningarna är gjorda av i första hand Marja ItkonenKaila och kompletterade av Pekonen, och de är försedda med relativt sparsamma men lagom förklarande fotnoter. I motsats till abbé Outhiers skrifter har Maupertuis egna skildringar om Lappland tidigare inte utgivits på finska.

Varför kom då Maupertuis till Lappland? En grundläggande fråga för den moderna kartografin under nya tiden var den om jordens form. Den var rund men inte symmetrisk, vilket sjöfarare sedan länge hade lagt märke till: sjökort som ritats utgående från att jorden var ett symmetriskt klot stämde inte och ledde till farliga situationer och grundstötningar. I början av 1700-talet fanns det två rivaliserande teorier om på vilket sätt jorden var deformerad: den franska, försvarad av lantmätardynastin Cassini, enligt vilken jorden hade formen av en på ändan ställd citron, alltså avsmalnade mot polerna, och på Newtons gravitationslära baserade engelska teorin, enligt vilken jorden var tillplattad vid polerna och alltså snarare liknade en mandarin. Maupertuis, som var hemma från Saint-Malo vid kanalkusten, hade liksom Voltaire och Madame du Châtelet övertygats om att engelsmännen hade rätt. För att få reda på hur det egentligen förhöll sig beslöt franska vetenskapsakademin i mitten av 1730-talet att sända ut två expeditioner för att mäta jordens form, den ena till ekvatorn och Peru under ledning av Godin och La Condamine, den andra till polcirkeln och Lappland under ledning av matematikern Maupertuis.

Expeditionen till Tornedalen blev en succé och kom att visa att Maupertuis och engelsmännen hade rätt. Med på expeditionen var förutom Maupertuis själv även tre andra franska matematiker och astronomer: Charles Camus (1699-1768), Alexis Clairaut (1713-1765) och Pierre Le Monnier (1715-1799). Med dem följde också abbé Réginald Outhier (1694-1774), som fick en mycket viktig roll som sekreterare och kartograf. Förutom att han var präst var han också korresponderande medlem av vetenskapsakademin och hade ett gott förhållande till Cassini, vilket underlättade mottagandet av expeditionens resultat. Dessa deltagare presenteras utförligt $i$ en av essäerna i boken. Därtill fick de hjälp av Anders Celsius (1701-1744), som skaffade behövliga geodetiska instrument från London, och av den lokala kanslisten Anders Hellant (1717-1789), som fungerade som tolk. Det var bland annat tack vare samarbetet med Celsius som just Tornedalen valdes som föremål för expeditionen.

Denna innebar en kort men intensiv växelverkan mellan den franska och europeiska vetenskapsvärlden och det svenska och lappländska lokalsamhället. Kretsen kring Maupertuis representerade den stora världen, med nätverk i Paris, Basel, Berlin och London och kontakter till samtidens viktigaste vetenskapsmän och filosofer. Samarbetet med lokalbefolkningen fungerade dock väl, även om Maupertuis brev ger uttryck för en ömsesidig förundran. Medan han skildrar de finska nybyggarnas frugala klädsel och seder (och vita tänder), förundrar sig samerna över de märkliga instrument som reses på fjälltopparna och likt gudomligheters tempel bevakas dag och natt. Med det lokala prästerskapet var det antagligen lättare att diskutera vetenskap; konversationen gick naturligtvis på latin.

Expeditionen dokumenterades rigoröst, framför allt av abbé Outhier. Förutom de strikt geodetiska observationerna beskrevs även naturen, folket och sederna. Maupertuis observationer karakteriserades av objektivitet och naturvetenskaplig noggrannhet. Han 
offentliggjorde sina rön dels i det anförande han höll inför franska vetenskapsakademin efter expeditionen och som trycktes 1738 under titeln La figure de la Terre, dels i en reseskildring om Vinsastenen i Pajala i nuvarande Norrbotten, Relation d'un voyage fait dans la Laponie septentrionale, uppläst i preussiska vetenskapsakademin i Berlin och tryckt 1747. Båda ingår i finsk översättning av Marja Itkonen-Kaila i boken, under titlarna "Maan muoto" och "Käymäjärven kivi". Därtill ingår Maupertuis brev till d'Argenson, publicerat första gången 1737, och till grevinnan Verteillac, publicerat första gången 1820. Dessa är mindre objektiva och mer underhållande och typiska exempel på 1700-talets konverserande epistolära stil. Som grund för översättningarna har Pekonen och Itkonen-Kaila använt så ursprungliga textversioner som möjligt; varianterna finns kommenterade i Pekonens och Vasaks franska utgåva från 2014.

Den geodetiska expeditionens följder var betydande. Dels bevisades teorin om att jorden på grund av sin rotation var tillplattad vid polerna. Dels blev den en av grunderna för det fransk-nordiska vetenskapliga samarbetet, som under de kommande årtiondena fortsatte livligt mellan vetenskapsakademierna (den svenska grundades år 1739) och som sedermera kom att kretsa uttryckligen kring betydelsen av det nordiska läget.

Expeditionen hade också konsekvenser på ett mänskligt plan. Den mest berömda av dessa mer anekdotiska följder är historien om systrarna Christine (f. 1716) och Elisabeth (f. 1718) Planström, döttrar till rådmannen i Torneå Jakob Planström, hos vilken en del av expeditionen var inkvarterad. De unga kvinnorna förälskade sig i matematikerna, Christine i Maupertuis och Elisabeth i någon av de andra, och följde dem tillbaka till Frankrike, där Christine sedermera gick i kloster och Elisabeth blev olyckligt gift. Historien har berättats i många sammanhang, bland annat av Inkeri TuomikoskiDombre i Voyageurs français en Finlande (1966), som dock inte nämns i den för övrigt mycket omfattande litteraturförteckningen i Maan muoto. De är också föremål för en av Pekonens sju essäer.

Bland de andra essäerna noterar man särskilt den om Outiers och Celsius meteorologiska observationer i Lappland, den om de geodetiska instrumenten (skriven med Johan Stén) och den om Maupertuis åminnelse i form av porträtt, medaljer, frimärken, monument och gatunamn. Den sistnämnda utgör en värdig avslutning på en trevlig och rikligt illustrerad populärhistorisk bok, som lämpar sig för många olika typer av vetgiriga läsare.

\author{
Charlotta Wolff \\ FT, dosentti, Suomen historian ma. professori \\ Turun yliopisto \\ charlotta.wolff (apud) utu.fi
}

